\title{
Chapter 9: The Impact of Gender Quotas on Voting Behaviour in 2016
}

\section{Gail McElroy}

\section{Introduction}

In 2016 the Republic of Ireland joined over fifty countries worldwide in the adoption of candidate gender quotas. Introduced via the Electoral Reform Act of 2012, this quota stipulated that the slate of candidates running for each party be composed of no less than thirty per cent of either gender, which effectively meant Irish parties had to find a lot more women to run in a very short space of time. Parties failing to reach this threshold would be punished by the halving of their state funding for the duration of the upcoming legislative term. Given the heavy reliance of political parties on state monies and the possible negative electoral consequences for failing to nominate sufficient numbers of women, it is not surprising that there was a large increase in the number of female candidates selected to run in 2016. In 2011 a mere 86 women ran for election, compared with 163 five years later. This sudden influx of a very large number of female nominees into the candidate pool offers us an excellent opportunity to definitively examine whether Irish voters are truly gender blind.

Previous research (McElroy and Marsh, 2010; 2011) has found little evidence of voter prejudice against female candidates. Nonetheless, as recently as January 2016, the country had the ignominious honour of ranking 111th in the world in terms of the number of women it elected to its lower house (a position it shared with both Koreas). The upward trend, visible in other European democracies in the past two decades, in the percentage of women elected to national assemblies had not been mirrored in Ireland, where the per cent of female TDs had stagnated in low double digits for years. The question of why a country which does rather well on other measures of gender equality (e.g. the World Economic Forum's Gender Index) and where voters are seemingly gender blind does not manage to elect more women to its parliament is puzzling. Ireland is a better country than most in which to be a woman, in terms of educational, health and economic indicators, but this is not reflected in levels of political representation.

Much of the blame for this lack of progress has been levelled at political parties failing to nominate women to run (McGing, 2013) and the new gender quota was designed to resolve this very issue. But a lingering question over voter bias remains. International experimental research regularly demonstrates voter bias against female candidates (Fox and Smith 1998; Smith et al. 2007), but aggregate and public opinion analysis fails to replicate this (Black and Erikson, 2003; Dolan, 1998; Seltzer et al., 1997). Recent attempts to 
reconcile these seemingly contradictory findings suggest that there is a quality gap between male and female candidates and that failure to control for this accounts for the puzzling results (Anzia and Berry, 2011; Fulton, 2012). This emerging body of work argues that male and female candidates are not equivalent; women who run for office are, on average, more accomplished and capable than their male contenders and this quality gap masks voter bias. Female candidates confront greater hurdles in the selection process for any number of reasons: a lack of self-belief, (Lawless and Fox, 2005), greater competition to be chosen (Lawless and Pearson, 2008), or outright selectorate bias (Sanbonmatsu, 2006). Thus, women who manage to get selected and survive the ardours of the campaigning process are of very high quality and voters recognizing this reward them with their vote. However, with the introduction of the quota in 2016 we essentially have an exogenous shock to the system: parties were forced to find a large number of women very quickly, so the recruitment pool is likely to have more 'average' women in it. As such, we can now test for true bias amongst the Irish electorate.

In what follows, we first examine the aggregate data for evidence of voter bias, both historically and in 2016. We then explore the individual level survey evidence from the exit poll data, and finally we use some new individual level data on voter traits to examine if there is a personality type that is predisposed to voting for female candidates.

\section{The Historical Context}

The number of women running in Irish elections has, historically, been very low, so low in fact that until the 1970s the absolute number of women competing at election time rarely reached double digits and, even then, many of these were what might be classified as 'honorary men' - the widows, daughters and sisters of dead male TDs. For instance, of three women elected to the Dáil in 1965, one was a daughter and two were the widows of former TDs (indeed one of them - Brigid Hogan Higgins - was also married to a sitting male TD). Similarly, in 1954 only five women were elected to the Dáil and four of these were the widows of former TDs, first elected after a husband's death left the spot vacant.

However, there was a significant increase in the number of women running for election in the 1970s and 1980s, as illustrated in Figure 9.1, in parallel with the rise of the international women's movement and Irish membership of the European Economic Community. 
In the 1973 general election only 5 per cent of candidates for the Dáil were women but by 1992 this figure had risen to 18 per cent. However, the number of women running for office plateaued in the mid 1990s and there was even a decline in the per cent of women running in the first three elections of the $21^{\text {st }}$ century. In 2011, a mere 86 of the 566 candidates on the ballot were women, representing slightly more than 15 per cent of the total. The two largest parties, Fianna Fáil and Fine Gael, particularly struggled to nominate women at recent elections. As Figure 9.2 demonstrates, the number of women running for both of these parties never exceeded 18 per cent from 2002 to 2011 (Fine Gael in 2002) and has been as low as 13 per cent (Fianna Fáil in 2007).

\section{FIGURE 9.2 ABOUT HERE}

In part, the problem is that incumbency is such a strong predictor of getting re-elected in Ireland (Matland and Studlar, 2004) and most incumbents are men (especially in the two largest parties). Parties naturally re-nominate these candidates as part of their seat maximization strategy. On the other hand, 85 per cent of non-incumbents running in 2011 were also men. In a gender-neutral environment, even with deference to the re-selection of incumbent male TDs, one might reasonably expect non-incumbents to divide roughly equally (with some volatility) amongst male and female candidates. In 2011, only 20 per cent of non-incumbent Fianna Fáil candidates were women (the equivalent figure for Fine Gael was also 20 per cent, while it was 23 per cent for Labour). Until 2016, the main political parties were simply not selecting women to run. An exploration of the reasons for this failure to nominate women is beyond the scope of this chapter, but runs the gamut from outright bias to a lack of women candidates coming forward. Here we will rather focus on what happens when women actually do run. Have Irish women done as well as men when their names are on the ballot?

The first cut at this question examines the evidence from the aggregate data on all candidates who ran for the Dáil from the early 1970s onwards (given how few women ran prior to this, there is little point in extending the analysis further back in time). In total there were 3,668 candidacies across the 12 elections held between 1973 and 2011, of which just under 16 per cent were female. Using a logit model where the dependent variable simply captures whether or not a candidate won a seat (with win coded as 1; 0 otherwise) and only four independent variables that capture the gender of the candidate ( 1 if female; 0 otherwise), 
their incumbency status ( 1 if an incumbent; 0 otherwise) and their party affiliation (plus an interaction term between incumbency and gender), we find gender is almost never significant in explaining who wins in Irish elections. The sample is divided into two different time periods, 1973 to 1989 and 1992-2011, to reflect the significant societal changes that occurred in the almost forty years under exploration. The odds ratios for women winning across the two periods are presented in Figure 9.3.

\section{FIGURE 9.3 ABOUT HERE}

Even in this simple model, the results indicate that women were not statistically significantly less likely to win than men, across either time period. The only exception is for female challengers running for Fianna Fáil in the post 1992 era, where femaleness does appear to be a slight disadvantage. Furthermore, this Fianna Fáil effect also verges on significance for the party's incumbents in the pre-1992 era. It is, additionally, worth noting that the sign on gender is negative for almost all parties in Figure 9.3, for both challengers and incumbents in the main parties across both time periods, though the effect is not a strong enough to have appreciable consequences for winning or losing. The aggregate historical analysis, thus, suggests women do tend to do a little worse in most parties but only significantly so in Fianna Fáil. The fact that there remain so few women in the Dáil appears to largely have been a problem at the nomination, as opposed to the election, stage. So what happens when, a lot, more women run?

\section{Aggregate Analysis 2016}

The anticipated impact of the gender quota was the subject of considerable media coverage in the run-up to the election. In particular, speculation was rife as to whether the two biggest parties would be able to meet the 30 per cent threshold or whether they would, at the close of nominations, simply run a bunch of 'no-hoper' female candidates to satisfy the requirement. Fianna Fáil was particularly challenged, in that they had failed to elect a single woman in 2011. To meet the gender quota, party headquarters had to introduce a gender directive to compel local selection conventions to nominate more women (in some cases quite controversially: e.g. Longford Westmeath). As was clearly demonstrated in Figure 9.2, the rise in the percentage of women running was highest for both of the largest parties, Fianna Fáil and Fine Gael. Fine Gael ran 27 women in 2016 compared with only 16 in 2011, while Fianna Fáil doubled the number of women it ran from 11 to 22 . A total of 551 candidates 
competed in the general election in 2016, 163 women and 388 men; this represents an increase of over seventy female candidates on the previous election.

As an aside, we find that there was quite a gendered difference in attitudes to the introduction of the quota amongst candidates. Figure 9.4A indicates that there was a clear disparity in the levels of support for the quota amongst male and female candidates, with over twice as many female candidates strongly supporting (point 10 on this $0-10$ scale) the initiative, compared with male candidates. ${ }^{1}$ This gender difference was not evident amongst voters, as data from the exit poll (INES1) presented in Figure 9.4B indicate (using the same scale). Overall however, support for the quota was higher amongst candidates with 44 per cent strongly supporting the initiative (giving a response of 8,9 or 10) compared with just 31 per cent of voters. That being said, there was very little opposition to the quota either with only 13 per cent of voters and 19 per cent of candidates being strongly opposed (a $0,1,2$ response).

\section{FIGURES 9.4A AND 9.4B AROUND HERE}

To test whether or not gender affected electoral performance in 2016, we again use aggregate data on all the candidates, but this time include a larger set of variables in the model to try and capture how quality, in particular, may interact with gender to affect the inclination to vote for a woman. Additionally, the dependent variable is also a little more nuanced, taking two forms; first we use the percentage of a quota that each candidate achieved, and second we calculate the degree to which each candidate's total vote deviated from the mean first preference vote in the constituency. ${ }^{2}$ This latter variable captures the extent to which a given candidate exceeds (or falls below) the average number of first preference votes received by other candidates in his or her constituency. Specifically, the dependent variable $\left(\mathrm{V}_{\mathrm{dev}}\right)$ measures candidate i's deviation from the mean candidate first preference vote in his or her constituency, where $\mathrm{V}_{\text {cmean }}$ gives the mean vote for candidates in

\footnotetext{
${ }^{1}$ Exact question wording was as follows: 'Candidate gender quotas for political parties were introduced for these elections to the Dáil. How much do you support the use of gender quotas for national elections on a scale from 0 to 10 where 0 means strongly oppose and 10 means strongly support?'

${ }^{2}$ Under the Single Transferable Vote system measuring candidate 'success' is not trivial. While winning a seat is what candidates ultimately care about, this dichotomous measure is somewhat crude and loses a lot of the information available on candidate performance. There are several alternative measures available such as share of the vote, share of a quota, absolute number of votes (controlling for votes cast in each constituency), deviation from the average share won by candidates from a district and deviation from the average share won by the candidate's party in a district. These measures are correlated with each other but far from perfectly, and this matters when we are examining levels of significance. Given no strong theoretical reason to use one measure over another, we deploy three alternative measures of success in this chapter.
} 
a constituency and $\mathrm{V}_{\mathrm{ci}}$ gives candidate i's vote total

$$
\mathrm{V}_{\mathrm{dev}}=\left(\mathrm{V}_{\mathrm{ci}}-\mathrm{V}_{\mathrm{cmean}}\right) / \mathrm{V}_{\mathrm{cmean}}
$$

This approach is intended to capture how well a candidate did, in terms of his or her total number of first preferences, relative to other candidates in the election, controlling for the different number of votes cast in each constituency. The correlation between the two dependent variables is, as one might expect, very high, but we use both as they capture slightly different aspects of electoral performance.

The key variable of interest in the analysis is, again, the candidate's Gender but we also control for a number of other characteristics. In particular, we are interested in measuring the 'quality' of a candidate, though the concept is notoriously difficult to operationalize, especially for challengers. In general, the literature has focused on quality as measured in terms of political experience, especially incumbency status (Squire, 1992; Van Dunk, 1997; Kulisheck and Mondak, 1996) and has found that this has a positive impact on election outcomes. We thus control for the incumbency status of each candidate and additionally ministerial experience (arguably those chosen for ministerial positions should be of even higher quality than backbenchers). Of course, these two variables may not measure quality per se, but rather may capture name recognition or an ability to deliver pork (the latter is especially relevant for the ministerial variable). And, even more importantly, neither of these variables helps us differentiate between high-quality and mediocre non-incumbents. While incumbent performance is directly observable to voters and thus should be easy for them to evaluate (see, however, the discussion in Wlezien, 2016) the question of how to assess challenger quality is more problematic. To attempt to get some further leverage over candidate quality, we also control for whether or not the candidate has served as a County or City Councillor. This measure may also be tainted by a degree of name recognition but it does capture some aspect of quality for challengers or, at least, an ability to win a race. Fiftyone per cent of candidates in 2016 were or had been councillors at some stage. Although only 43 per cent of women had been councillors, compared with 56 per cent of male contenders.

Finally, we also control for campaign spending (measured as per cent of the spending limit) as previous research has found a positive relationship between spending and votes (Benoit and Marsh, 2010), especially for challengers. Arguably the ability to raise significant funds is also a measure of candidate credibility and quality or, at a minimum, campaign effort (admittedly, very safe candidates may have to spend very little money, but given the low 
limits on campaign spending in Ireland, this endogeneity issue is perhaps less of an issue than in the United States). None of the candidates running in 2016 breached the constituency spending limits and over 80 per cent spent less than half the permissible amount. ${ }^{3}$ There appears to be no significant gender differences in spending, even if we confine the analyses to the four main parties. But incumbents spend far more than non-incumbents in general, though this divergence disappears if we confine our analyses to the big players (Sinn Féin, Labour, Fine Gael, Fianna Fáil). The model also includes a series of interaction terms: we interacted candidate gender with incumbency, ministerial status and party affiliation.

A linear regression model was run using both dependent variables and as is clear from Figure 9.5 the Gender of the candidate is once more insignificant. ${ }^{4}$ Incumbency is a strong predictor of vote getting, as is being a councillor. Campaign spending was also highly predictive of getting a bigger per cent of the quota or a higher than average number of $1^{\text {st }}$ preference votes. None of the interaction terms reached standard levels of significance with the, interesting, exception of Gender interacted with running for Fianna Fáil, which was again negatively signed (see Models 1 and 2 in Table A9.1). Thus, it does seem to be the case that women running for Fianna Fáil do worse than their male co-partisans. This pattern corroborates what we saw from the analysis on the previous twelve elections. Fianna Fáil voters do seem to prefer male candidates, which in light of the requirement to have 40 per cent of female candidates at the next general election does not bode well for the party's prospects of regaining their position as the poll topper.

\section{FIGURE 9.5 ABOUT HERE}

In an ideal world we would have far better measures of candidate quality, such as details like candidate work histories and educational attainment, though whether voters have this level of knowledge about challengers and act on it is debateable. In the field of economics, candidate quality is typically measured in terms of years in full time education (e.g. Baltrunaite, 2014) and in future work collecting and coding this variable for all candidates will be worthwhile. But as one final check of the impact of quality on election outcomes, we also ran a model with a crude control for educational attainment. Given the difficulty of collecting these data, the sample is much smaller, with information available for only 273 of the candidates (just under 50 per cent of the total). This includes all those who

\footnotetext{
${ }^{3}$ Campaign spending limits were as follows: $€ 30,150$ in three seat constituencies, $€ 37,650$ in four seaters and $€ 45,200$ in five seaters

${ }^{4}$ Not all variables in the model are presented in Figure 9.5. For those, see Table A9.1 in the Appendix.
} 
were elected (for whom biographical information is more readily available) and 129 of the unsuccessful candidates. This trichotomous variable differentiates between those who do and do not have a primary degree and those with advanced qualifications. Exactly 50 per cent of this sample had a primary degree or equivalent and 23 per cent had an advanced degree, with the remaining 26 per cent having a primary school, secondary school or non degree-level qualification. There was a distinct gender division on this variable, with 31 per cent of female candidates having a postgraduate qualification compared with just 20 per cent of men.

With due consideration to the caveat that the analysis is only run on half the universe of candidates and this is almost certainly not a representative sample, the same regression models were run as before with the inclusion of the variable for educational achievement (and a term interacting education and gender). ${ }^{5}$ The results are presented in Figure 9.6: yet again, the gender of the candidate is not significant but having served as a councillor, total spend and incumbency remain so. Education is, additionally, a predictor of obtaining a higher percentage of the quota, even when measured crudely in this trichotomous fashion (though the interaction of education with candidate gender is not, as is demonstrated in models 3 and 4 in Table A9.1). ${ }^{6}$ Thus candidate quality, however measured, does seem to matter to Irish voters; however, it does not seem to have a gendered dimension to it. There is clearly considerable scope for exploration of this quality dimension in future work and, in particular, data on years in fulltime education for all candidates should be collated.

\section{FIGURE 9.6 ABOUT HERE}

All in all, it would seem that the introduction of a large number of women into the mix in 2016 did not reveal any previously hidden biases amongst Irish voters. Female candidates are not disadvantaged in the bid to get elected (except for Fianna Fáil); what matters is already having a seat in the Dáil, prior political experience at the local level and having money to spend. In the next section we move beyond the aggregate data and analyse INES data to investigate if the individual level data reveal any discrimination against female candidates, or to establish if there is a particular type of voter who is more inclined or disinclined to vote for a woman.

\footnotetext{
${ }^{5}$ In particular we almost certainly underrepresent less educated challengers, independents especially, if this is the case we expect the effect of the education measure to be attenuated.

${ }^{6}$ Interestingly, the interaction term between Gender and Fianna Fáil drops from significance in these models.
} 


\section{Individual Level Voting data}

The aggregate analysis did not reveal anything to suggest that female candidates do systematically worse than their male counterparts in elections in Ireland, but is it the case that there are types of voters that are more or less disposed to voting for female candidates? Are there individuals who are biased in their voting behaviour? Are women more likely to vote for female candidates for instance or are those with a right wing leaning more likely to favour men? These questions can only be answered by examining the individual level data from the post election INES surveys (INES2 and INES3).

We make use of two separate dependent variables in the analysis that follows. The first, PREFERENCE, captures whether or not the respondent expressed any preference for a female candidate; the second, HIGH PREFERENCE, captures whether or not the respondent gave a top preference (a first, second or third) to the candidate in question. The independent variables in the analysis include the demographic and attitudinal characteristics of voters that might influence their propensity to vote for a woman candidate: WOMAN VOTER, AGE, EDUCATION, CLASS, QUOTA SUPPORT, IDEOLOGY, PARTY ID and PARTY CENTRED VOTER, and we also control for whether the candidate voted for was an INCUMBENT or a PARTY CANDIDATE. The key variable of interest is WOMAN VOTER, which is intended to capture the propensity of women to vote for women, (measured as a standard dichotomous variable: 0 if the respondent is male and 1 if female). $A G E$ is measured across eight cohorts (ranging from the youngest group of voters aged 18-22 to the oldest who are $65+$ ). The expectation is that younger people will be more open to voting for women. EDUCATION is a trichotomous variable that distinguishes those who did not complete secondary school education, from those with a secondary level qualification from those with a $3^{\text {rd }}$ level qualification, with the latter theorized to be most likely to vote for female candidates. CLASS is a dichotomised variable that divides the population between the middle class $\mathrm{ABC} 1$ group and the rest. ${ }^{7}$ Surprisingly, this latter variable is not especially highly correlated with education (0.4), perhaps reflecting the crude measurement of both. QUOTA SUPPORT is an 11-point scale capturing the voter's attitudes towards the introduction of the gender quota (0 strongly opposed, 10 strongly support). Given the brevity of the surveys, there are no specific ideological questions that capture a voter's attitudes to feminist issues but we do control for IDEOLOGY, as measured through general left-right self-placement, reasoning that more left wing voters will have more progressive attitudes to issues such as the election of women to the Dáil (though see McElroy 2017 for a discussion of how the super dimension

\footnotetext{
${ }^{7}$ An alternative categorization of large farmers (50+ acres) with the $\mathrm{ABC} 1$ grouping does not affect the results.
} 
Left-Right in Ireland is not underpinned by coherent ideological dispositions). We also include a variable, PARTY ID, which measures the strength of the respondent's party identification; we reason that where this is strong, the voter will be driven to vote the party line regardless of the gender of the candidate. PARTY ID is measured using a dichotomous variable, where 1 is feeling close to a particular party and 0 is not. PARTY CENTRED VOTER captures how important the candidate rather than the party is for the respondent. This measure is a three-point scale and ranges from -1 (candidate centred) to 1 (party centred). ${ }^{8}$ Given the results of the aggregate analysis, we also control for whether the candidate was an INCUMBENT and running for a party to which the voters was close (PARTY CANDIDATE). We also include interactions between female respondent and all of these variables to see if there are some particular types of female respondents who are more inclined to vote for women.

Figure 9.7A and 9.7B presents the results of this analysis for the two separate logit models. It is important to note that the analysis here is confined to female candidates, but results are equivalent to a model in which both male and female candidates are included. ${ }^{9}$ As is clearly evident from these figures, the results fail to find any evidence in favour of the hypothesis that women voters favour female candidates; nowhere does WOMAN VOTER reach significance. Similarly, AGE, IDEOLOGY and QUOTA SUPPORT are all insignificant. Attitudes to the introduction of the quota do not seem to impact on a voter's propensity to vote for a female candidate, nor is ideological self-placement significant: there is no difference between right and left wing voters in their willingness to vote for a woman. Nor do we find evidence that any particular sub-group of women respondents is more inclined to vote for women candidates (none of the interaction terms are significant in either of the models and as such are not presented in the figures, but full results are presented in Table A9.2 in the appendix for the interested reader). We do, however, find that more educated and middle class voters are slightly more inclined to express a preference for a woman and education is on the verge of significance for high preference voting also (though the class effect is not). But overall, what seems to matter to voters when they choose to give a vote to a woman, echoing the findings from the aggregate analysis, is that the candidate in question is an incumbent and running for a party they are close to.

\section{FIGURES 9.7A AND 9.7B AROUND HERE}

\footnotetext{
${ }^{8}$ For more details see Marsh et al. (2008, Chapter 8) and Courtney and Weeks, this volume.

${ }^{9}$ By including male as well as female candidates, we would have to include third order interaction terms, which only serve to obscure the central findings.
} 
On the whole, the analysis in this section suggests that there are few identifiable characteristics of voters that make them more inclined to vote for a female candidate. These results echo much international survey research, which finds that voters do not differentiate between candidates on gender grounds. In the final section, we explore whether there are any distinguishing personality traits of those who vote for women.

\section{The Psychology of Voting for Women}

In the previous section we found that standard demographic characteristics such as class, age and ideology have little to no explanatory power in predicting who will vote for a female candidate. But are there certain types of people who are more likely to vote for women, in terms of their general personality dispositions?

A large body of research in psychology has established that there are five basic elements that account for differences in personality: Openness, Conscientiousness, Extraversion, Agreeableness, and Emotional Stability. The general hypothesis that personality affects all types of human behaviour is well established in empirical work and the five-factor model has become the cornerstone of trait psychology since the 1980s. While there are other approaches, these five broad elements are now largely accepted as jointly covering the majority of personality structure. Openness refers to 'the breadth, depth, originality, and complexity of an individual's mental and experiential life' (John et al., 2008: 120). Conscientiousness is identified as 'socially prescribed impulse control that facilitates task- and goal-directed behaviour, such as thinking before acting, delaying gratification, following norms and rules, and planning, organizing, and prioritizing tasks' (John et al., 2008: 120). People with high scores for Extraversion have 'an energetic approach to the social and material world [and it] includes traits such as sociability, activity and assertiveness, and positive emotionality" (John et al., 2008: 120). Agreeable individuals are "pro-social and communal in orientation as opposed to antagonistic to others, they display traits such as modesty, tender mindedness trust and altruism' (John et al., 2008: 120). Finally, Emotional Stability (also referred to as Neuroticism) contrasts traits such as nervousness, sadness and anxiety with even temperedness and general emotional well-being.

Three decades of study have finely tuned both the meaning and measurement of these concepts and this 'Big Five' model is now the 'the most widely used and extensively researched measure of personality' (Gosling et al., 2003: 506). Recent work in political science, drawing on this literature, has established that there is a significant relationship 
between these personality traits and ideological dispositions and, to a lesser extent, levels of political participation (Mondak, 2010; Gerber et al., 2011). In particular, it has been established that Conscientiousness is associated with conservative political values in voters (Alford and Hibbing, 2007; Gosling et al., 2003; Jost et al., 2003; 2007; Mondak, 2010), while those who are Open to new experiences tend to be more liberal (Carney et al., 2008; Schoen and Schumann, 2007). The findings with regard to the other three traits, Agreeableness, Extraversion and Neuroticism are, as of yet, less settled. While Agreeableness has been associated with, for instance, more liberal values in Italy and Germany the result has not been found to hold in studies of US voters. Although Emotional Stability has been found to predict ideological self-placement in both the US and Germany, the relationship is in the opposite direction, with high levels of Neuroticism being associated with centre-left voting in Germany but voting for the Republicans in the US (Schoen and Schumann, 2007; Mondak and Halperin, 2008). Finally, while Extraversion has been linked to levels of political participation, such as turnout, it has not been systematically associated with voter ideology, though those who score high on extraversion are more likely to be strong party identifiers (Gerber et al., 2011; 2012).

There is very little research on the 'Big Five' and Irish voters, however a brief battery of questions, which aimed to measure these traits in Irish voters, was included in the 2016 INES3 and here we examine if any of these personality dispositions is predictive of voting for women. The standard battery of 10 questions that captures the main underlying predispositions of personality was included in the telephone recall survey, conducted by Red $\mathrm{C}$, and we utilise these data to examine whether or not voting for women is associated with certain personality types (see Appendix Table A9.3 for the full set of questions). First, we explore whether we see similar patterns in personality difference between men and women in Ireland. Sex differences in personality traits have been found to be larger and more consistent (across time and culture) than sex differences in other domains such as cognitive ability or self-esteem (Else-Quest et al., 2006; Hyde, 2005). These differences in personality have been found to cross national borders. Feingold (1994) found that women in Canada, China, Finland, Germany, Poland, and Russia scored higher than men on scales related to the personality traits of neuroticism, agreeableness, and conscientiousness. Men scored higher in the extraversion-related trait of assertiveness. One slightly odd finding is that sex differences in personality traits are often larger in developed countries (Europe and North American) with egalitarian cultures, compared with Asian and African states (Costa et al., 2001; McCrae, 2002; Schmitt et al., 2008). Generally, the psychology literature has demonstrated that men 
tend to be more assertive than women, and women are generally higher than men in anxiety and tender-mindedness/sensitivity (Brody and Hall, 2000; Feingold, 1994; Kring and Gordon, 1998; Lynn and Martin, 1997). And indeed, as illustrated in Figure 9.8, we find that there are gendered differences on two of the five factors in Ireland - Neuroticism and Agreeableness, with women more like to describe themselves as sensitive than men but also more friendly. ${ }^{10}$ However, there are no significant differences in levels of conscientiousness and extraversion, which is at odds with the findings from most other advanced industrial democracies.

\section{FIGURE 9.8 ABOUT HERE}

Given these questions on personality were asked in a short telephone survey, conducted in the weeks after the election (INES3), we unfortunately do not have access to the full range of voting preferences provided by the mock ballots (INES1), which we used in the previous section. Respondents were, however, asked to name the candidate to whom they gave their first preference and in the following analysis we take advantage of this information to see if we can isolate personality traits that make a voter more likely to vote for a woman than a man. ${ }^{11}$ Given that the earlier analysis confirmed the importance of party for voters' first preference choice, we confine our analysis to those respondents who could choose between a male and female candidate running for the same party. This approach is necessarily restrictive and reduces the sample considerably, as Fine Gael only ran a male and a female candidate in 19 of 40 constituencies, while the equivalent figures for Fianna Fáil is 17, for Sinn Féin 6 and for Labour just 2. There were independent candidates of both genders running in 23 constituencies. Furthermore, we are forced to make the limiting assumption that party trumps gender in this particular model. We also do not have access to questions that would permit us to differentiate party centred from non-party centred voters. With these caveats in mind, we run a logit where the dependent variable codes voting for a female candidate as 1 ( 0 otherwise). The key variables of interest are the 'Big Five', as detailed above. Given other work in political science that finds Openness is correlated with liberal attitudes and Conscientiousness with conservative values, our expectation is that these will have the strongest influence on propensity to vote for female candidates (openness should be positively signed and conscientiousness negatively signed). Extraversion has not been found

\footnotetext{
${ }^{10}$ Distributional differences are statistically significant using a Kolmogorov-Smirnov test for Openness and Neuroticism.

11 Just slightly over three quarters of respondents could (or were willing) to name their first preference candidate, thereby reducing the sample.
} 
to correlate with voter ideology and the results on Neuroticism and Agreeableness vary by country, as such we have no strong expectations related to these three traits. We again control for the Age, Class, Gender, Education and Ideology of the voter, plus their attitude to the quota. We also control for whether or not the party (or independents taken as a group) to which the respondent gave his or her first preference had an incumbent female in the constituency, as incumbency has been found to be such a strong predictor of vote getting in the earlier sections.

The results of the logit model suggest that few of the 'Big Five' traits are significant predictors of giving a first preference to a woman. The only variable that was significantly related to giving a first preference to a female candidate was Openness to Experience, which captures a respondent's willingness to try new things and a degree of unconventionality. Extraversion is, surprisingly, negatively related to giving a first preference to a woman but this effect is only significant at the 0.1 level: in future work, with a larger sample and a more refined dependent variable, we will see if this relationship holds. Unsurprisingly, if the party of the candidate the respondent voted for has a female incumbent, the voter is more likely to vote for a female and interestingly, QUOTA SUPPORT does reach significance in this model. As is clear from Figure 9.9 most of the other variables in the model fail to reach standard levels of significance, but once more education and class are positively signed, a pattern that fits with the analysis in the previous section. Overall, the analysis suggests the more curious and less conventional are more likely to cast a vote for a female candidate. However, it is worth repeating, that this analysis of Irish voter traits and their impact on voting behaviour is in its infancy and future work, with higher quality data, is required.

\section{FIGURE 9.9 ABOUT HERE}

\section{Discussion}

The introduction of a gender quota bill in the Dáil in December 2011 by then Minister for the Environment Phil Hogan was unexpected in its timing. The Fine Gael-Labour government elected in February 2011 was dealing with an economy in meltdown and tasked with implementing punitive austerity measures, as a condition of the international financial bailout. Gender quotas, for an election that was likely to be more than four years down the line, did not seem like a top priority. While a handful of women's groups and academics had been lobbying for their introduction for some years, there was little public interest in or awareness of the gap in representation. Gender has never been very politicized in Irish electoral campaigns or, indeed, politics more generally. Furthermore, the quota was likely to pose a 
problem for the main governing party, Fine Gael, though clearly not as much of a problem as for its main rival, Fianna Fáil. Nonetheless, the bill became law in July 2012 and the 2016 general election was the first to operate under its provisions.

The quota had an immediate impact: the number of women running for and elected to the Dáil increased quite dramatically, though at just over 22 per cent of legislators, Ireland still falls well behind most other West European states in the ranking of women in its parliament. ${ }^{12}$ And while there was not much public demand for the introduction of the quota, there does not appear to have been any significant opposition to it once the legislation was enacted. There was no change in voting behaviour. Previous work has found the Irish electorate to be gender blind and 2016 was no different; people cast their ballot for candidates on the basis of their party affiliation, their political experience and their quality, more generally. We cannot find a subtype of voter, either in demographic or personality type, who is systematically more inclined to vote for a woman. Ideology, class and age don't consistently predict propensity to vote for women, nor does quota support. What matters most is that the candidate is a known entity; especially that he or she is an incumbent. The responsibility for so few women being elected in Ireland does not rest with the electorate, with, perhaps, the notable exception of those voting for Fianna Fáil. The aggregate and individual level data clearly suggests that this party's voters do actually have a preference for male candidates.

\footnotetext{
${ }^{12}$ For instance, of the 15 pre-2004 member states of the European Union, the only country with a lower figure at the time of writing -August 2017- was Greece (at 18.3 per cent).
} 


\section{References:}

Alford, J. R., \& Hibbing, J. R. (2007). Personal, interpersonal, and political temperaments. The Annals of the American Academy of Political and Social Science, 614(1), 196-212.

Anzia, S. F., \& Berry, C. R. (2011). The Jackie (and Jill) Robinson effect: Why do congresswomen outperform congressmen?. American Journal of Political Science, 55(3), 478-493.

Baltrunaite, A., Bello, P., Casarico, A., \& Profeta, P. (2014). Gender quotas and the quality of politicians. Journal of Public Economics, 118, 62-74.

Benoit, K., \& Marsh, M. (2010). Incumbent and challenger campaign spending effects in proportional electoral systems: The Irish elections of 2002. Political Research Quarterly, 63(1), 159-173.

Black, J. H., \& Erickson, L. (2003). Women candidates and voter bias: do women politicians need to be better?. Electoral Studies, 22(1), 81-100.

Brody, L. R., \& Hall, J. A. (2000). Gender, emotion, and expression. In M. Lewis \& J. M.Haviland-Jones ( Eds), Handbook of emotions: Part IV: Social/personality issues (2nd ed, pp. 325-414) New York: Guilford Press.

Carney, D. R., Jost, J. T., Gosling, S. D., \& Potter, J. (2008). The secret lives of liberals and conservatives: Personality profiles, interaction styles, and the things they leave behind. Political Psychology, 29(6), 807-840.

Costa Jr, P., Terracciano, A., \& McCrae, R. R. (2001). Gender differences in personality traits across cultures: robust and surprising findings.

Dolan, K. (1998). Voting for Women in the" Year of the Woman". American Journal of Political Science, 272-293.

Else-Quest, N. M., Hyde, J. S., Goldsmith, H. H., \& Van Hulle, C. A. (2006). Gender differences in temperament: a meta-analysis. Psychological bulletin, 132(1), 33.

Feingold, A. (1994). Gender differences in personality: a meta-analysis. Psychological bulletin, 116(3), 429.

Fox, R. L., \& Smith, E. R. (1998). The Role of Candidate Sex in Voter DecisionMaking. Political Psychology, 19(2), 405-419.

Fulton, S. A. (2012). Running backwards and in high heels: The gendered quality gap and incumbent electoral success. Political Research Quarterly, 65(2), 303-314.

Gerber, A. S., Huber, G. A., Doherty, D., Dowling, C. M., Raso, C., \& Ha, S. E. (2011). Personality traits and participation in political processes. The Journal of Politics, 73(3), 692-706.

Gerber, A. S., Huber, G. A., Doherty, D., \& Dowling, C. M. (2012). Personality and the strength and direction of partisan identification. Political Behavior, 34(4), 653-688.

Gosling, S. D., Rentfrow, P. J., \& Swann, W. B. (2003). A very brief measure of the Big-Five personality domains. Journal of Research in personality, 37(6), 504-528.

Hyde, J. S. (2005). The gender similarities hypothesis. American psychologist, 60(6), 581.

John, O. P., Naumann, L. P., \& Soto, C. J. (2008). Paradigm shift to the integrative big five trait taxonomy. Handbook of personality: Theory and research, 3, 114-158.

Jost, J. T., Glaser, J., Kruglanski, A. W., \& Sulloway, F. J. (2003). Political conservatism as motivated social cognition. Psychological bulletin 1293 (2003): 339

Kring, A. M., \& Gordon, A. H. (1998). Sex differences in emotion: expression, experience, and physiology. Journal of personality and social psychology, 74(3), 686-703.

Kulisheck, M. R., \& Mondak, J. J. (1996). Candidate quality and the congressional vote: A causal connection?. Electoral Studies, 15(2), 237-253.

Lawless, J. L., \& Fox, R. L. (2005). It takes a candidate: Why women don't run for office. Cambridge University Press. 
Lawless, J. L., \& Pearson, K. (2008). The primary reason for women's underrepresentation? Reevaluating the conventional wisdom. The Journal of Politics, 70(1), 67-82.

Lynn, R., \& Martin, T. (1997). Gender differences in extraversion, neuroticism, and psychoticism in 37 nations. The Journal of social psychology, 137(3), 369-373.

Marsh, M., Sinnott, R., Garry, J., \& Kennedy, F. (2008). The irish voter. MUP: Manchester.

Matland, R. E., \& Studlar, D. T. (2004). Determinants of legislative turnover: a cross-national analysis. British Journal of Political Science, 34(1), 87-108.

McCrae, R. R. (2002). Neo-PI-R Data from 36 Cultures. The Five-Factor Model of Personality Across Cultures, 105.

McElroy, G., \& Marsh, M. (2010). Candidate gender and voter choice: Analysis from a multimember preferential voting system. Political Research Quarterly, 63(4), 822-833.

McElroy, G., \& Marsh, M. (2011). Electing women to the Dáil: gender cues and the Irish voter. Irish Political Studies, 26(4), 521-534.

McElroy, G. (2017). Party Competition in Ireland. A Conservative Revolution?: Electoral Change in Twenty-First Century Ireland, 61.

McGing, C. (2013). The single transferable vote and women's representation in Ireland. Irish Political Studies, 28(3), 322-340.

Mondak, J. J. (2010). Personality and the foundations of political behavior. Cambridge University Press.

Mondak, J. J., \& D. Halperin, K. A. R. E. N. (2008). A framework for the study of personality and political behaviour. British Journal of Political Science, 38(2), 335-362.

Sanbonmatsu, K. (2010). Where women run: Gender and party in the American states. University of Michigan Press.

Schmitt, D. P., Realo, A., Voracek, M., \& Allik, J. (2008). Why can't a man be more like a woman? Sex differences in Big Five personality traits across 55 cultures. Journal of personality and social psychology, 94(1), 168.

Schoen, H., \& Schumann, S. (2007). Personality traits, partisan attitudes, and voting behavior. Evidence from Germany. Political psychology, 28(4), 471-498.

Seltzer, R., Newman, J., \& Leighton, M. V. (1997). Sex as a political variable: Women as candidates and voters in US elections. Lynne Rienner Publishers.

Smith, J. L., Paul, D., \& Paul, R. (2007). No place for a woman: Evidence for gender bias in evaluations of presidential candidates. Basic and Applied Social Psychology, 29(3), 225233.

Squire, P. (1992). Legislative professionalization and membership diversity in state legislatures. Legislative Studies Quarterly, 69-79.

Van Dunk, E. (1997). Challenger quality in state legislative elections. Political Research Quarterly, 50(4), 793-807.

Wlezien, C. (2016). On Causality in the Study of Valence and Voting Behavior: An Introduction to the Symposium. Political Science Research and Methods, 4(1), 195-197. 
Figure 9.1: Proportion of women running and elected in Irish elections 1948-2016

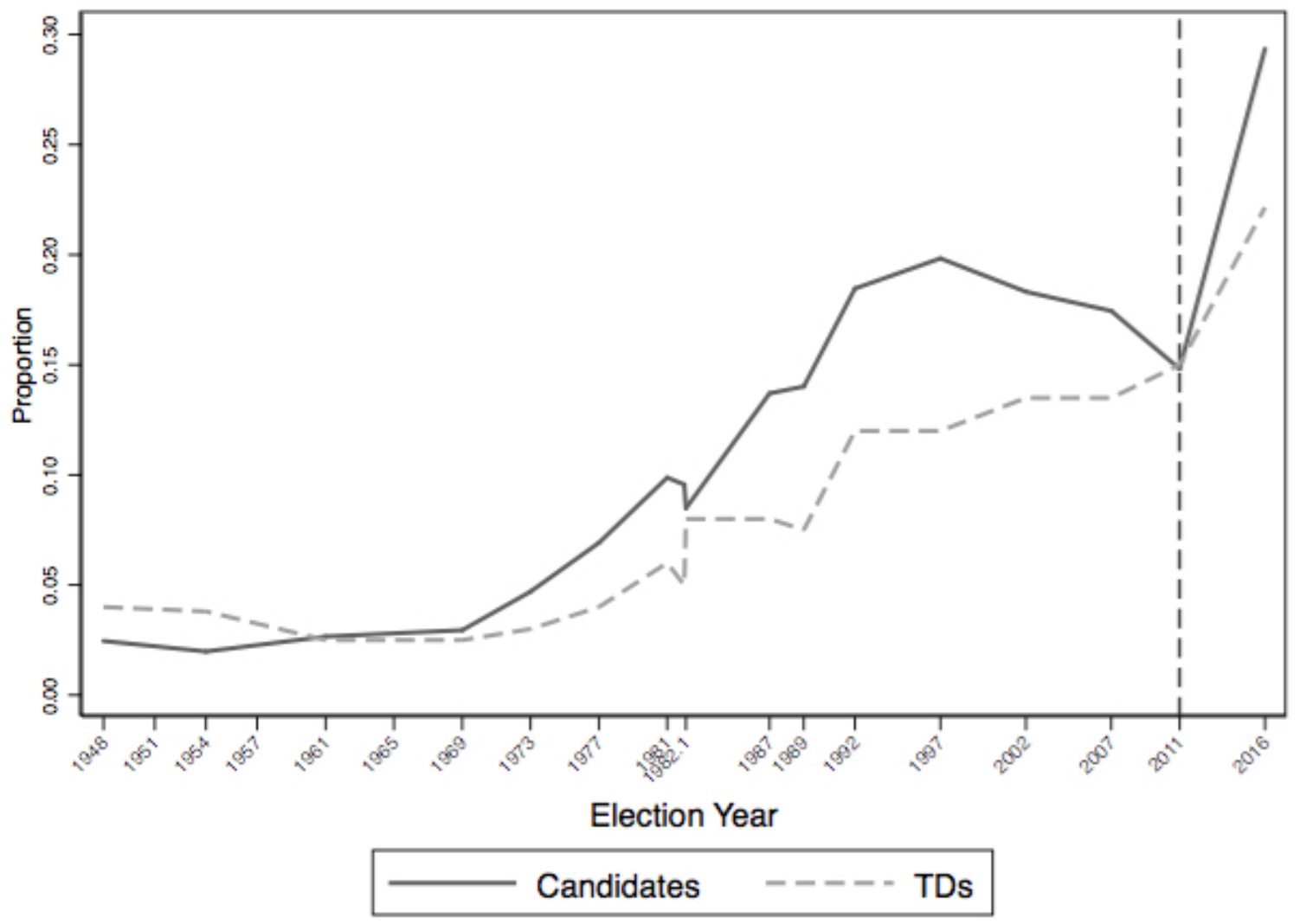


Figure 9.2: Proportion of women running for the four main parties 2002-2016

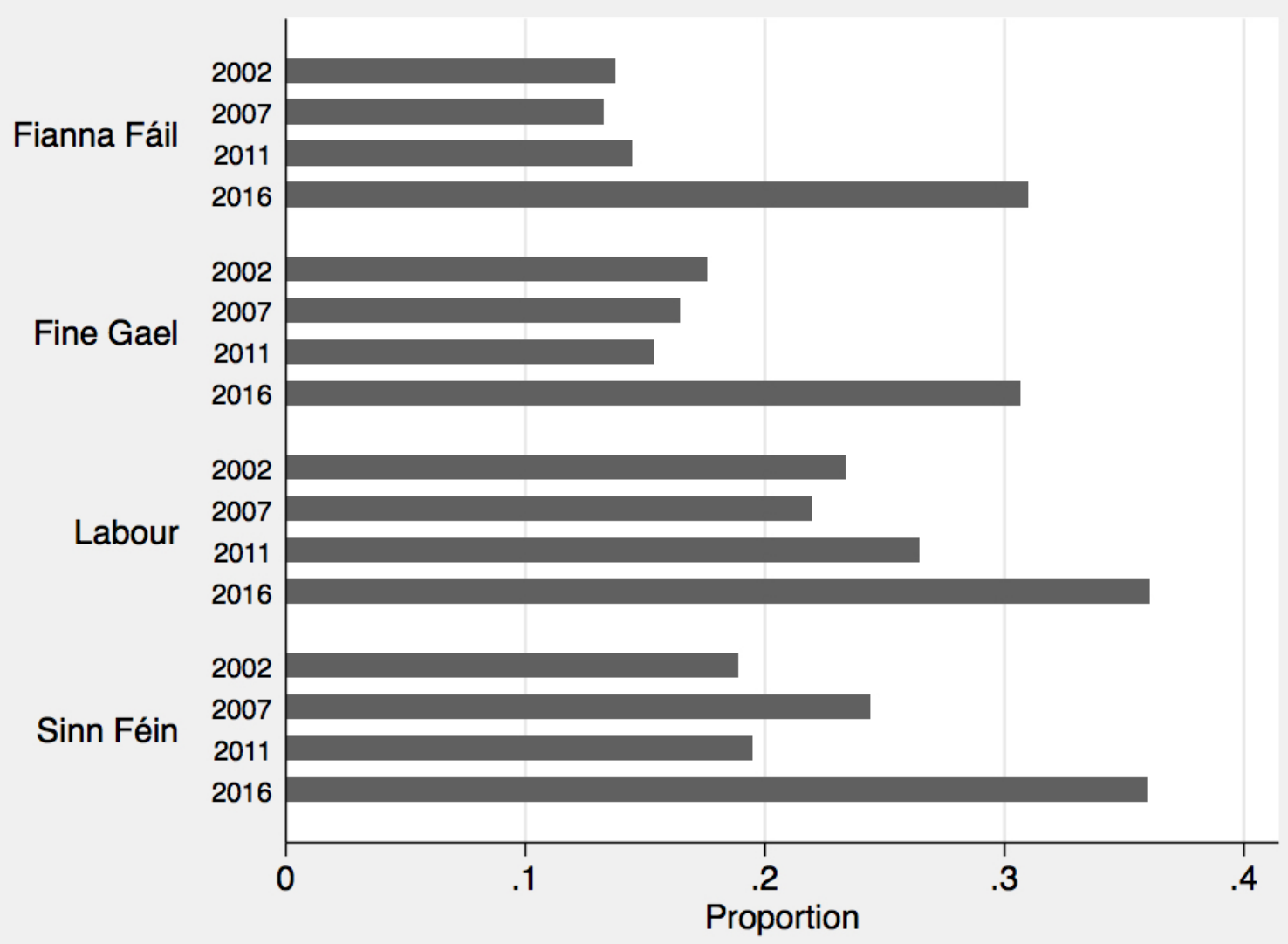


Figure 9.3: Odds of women winning 1973-2011

\section{Do women win?}
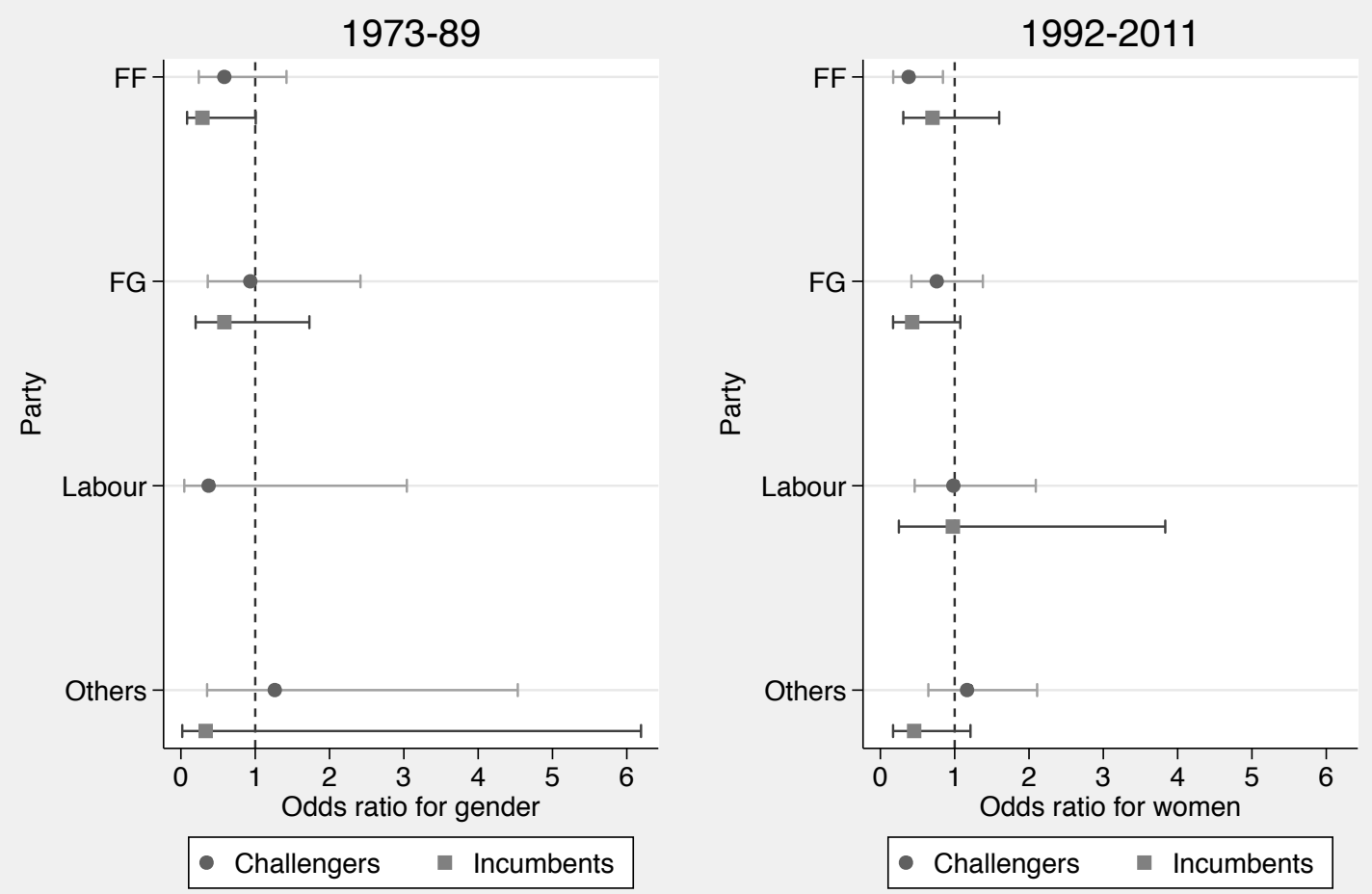

Note: Odds Ratios from logit analysis where dependent variable is losing (0) or winning (1). 
Figure 9.4A: Support for gender quota amongst general election candidates

Candidates 2016

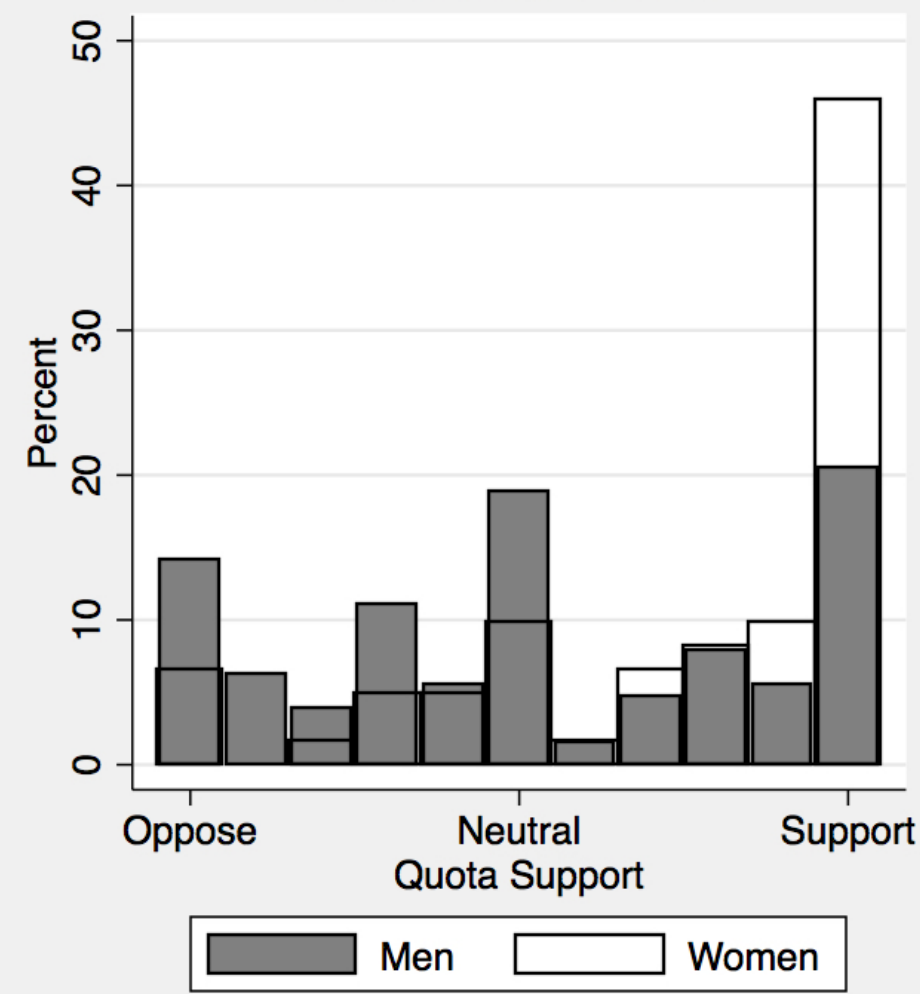

Data Source: Irish Candidate Study 2016. 
Figure 9.4B: Support for gender quota amongst voters

\section{Voters 2016}

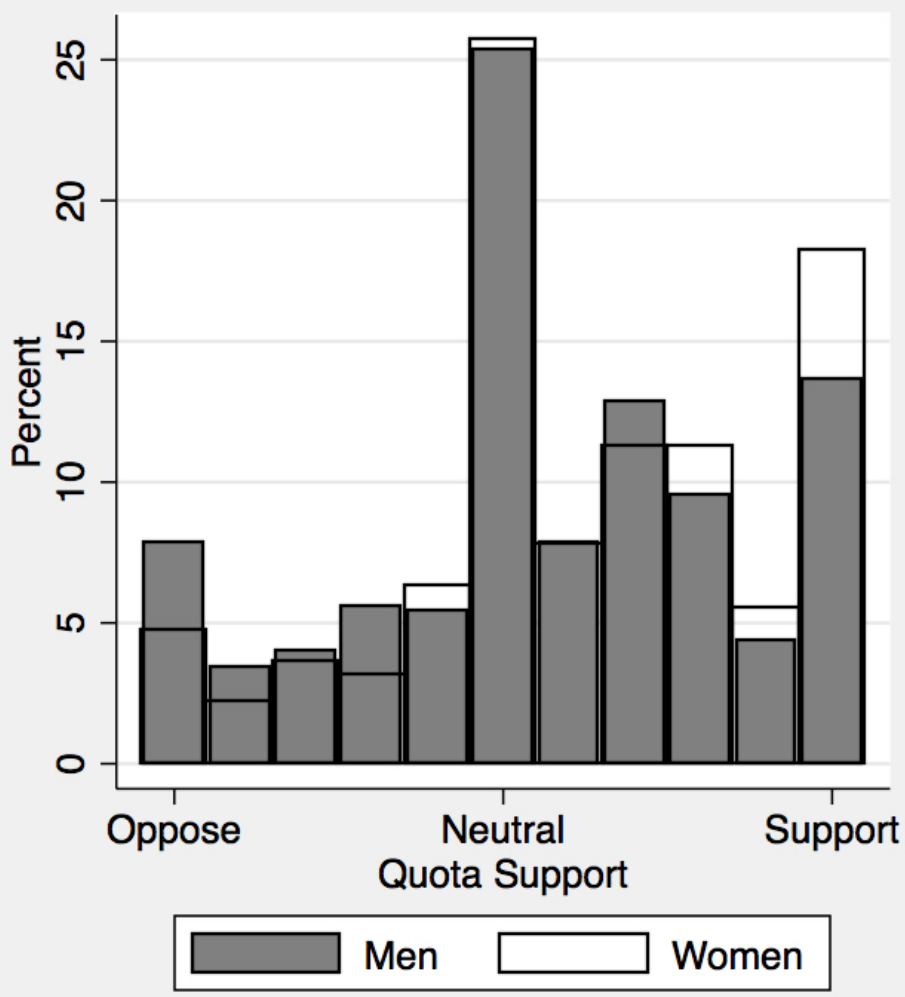

Data Source: INES1 
Figure 9.5: Impact of Gender on candidate success 2016

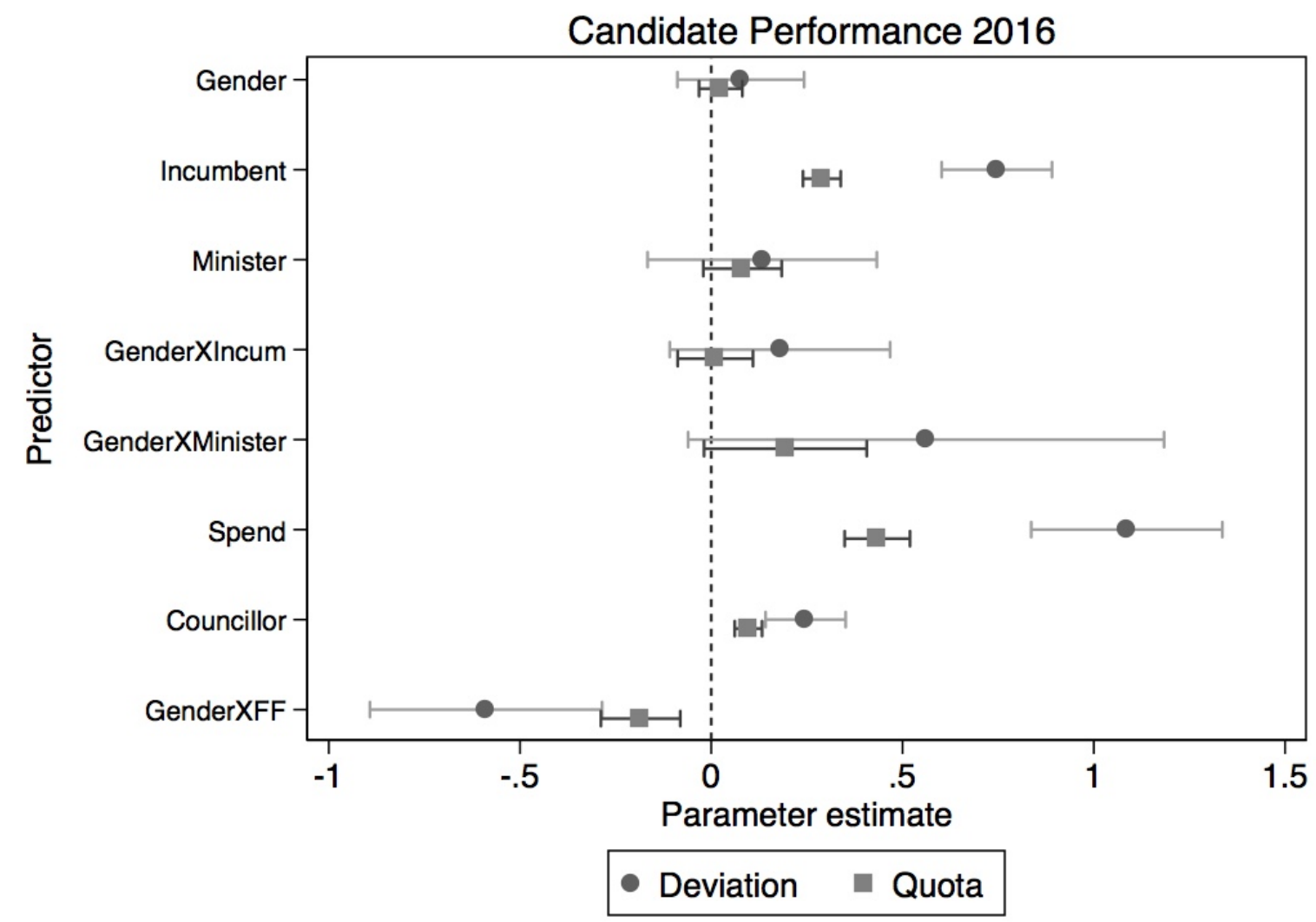


Figure 9.6: Impact of candidate gender and education on success 2016. Note: Sample Size 272

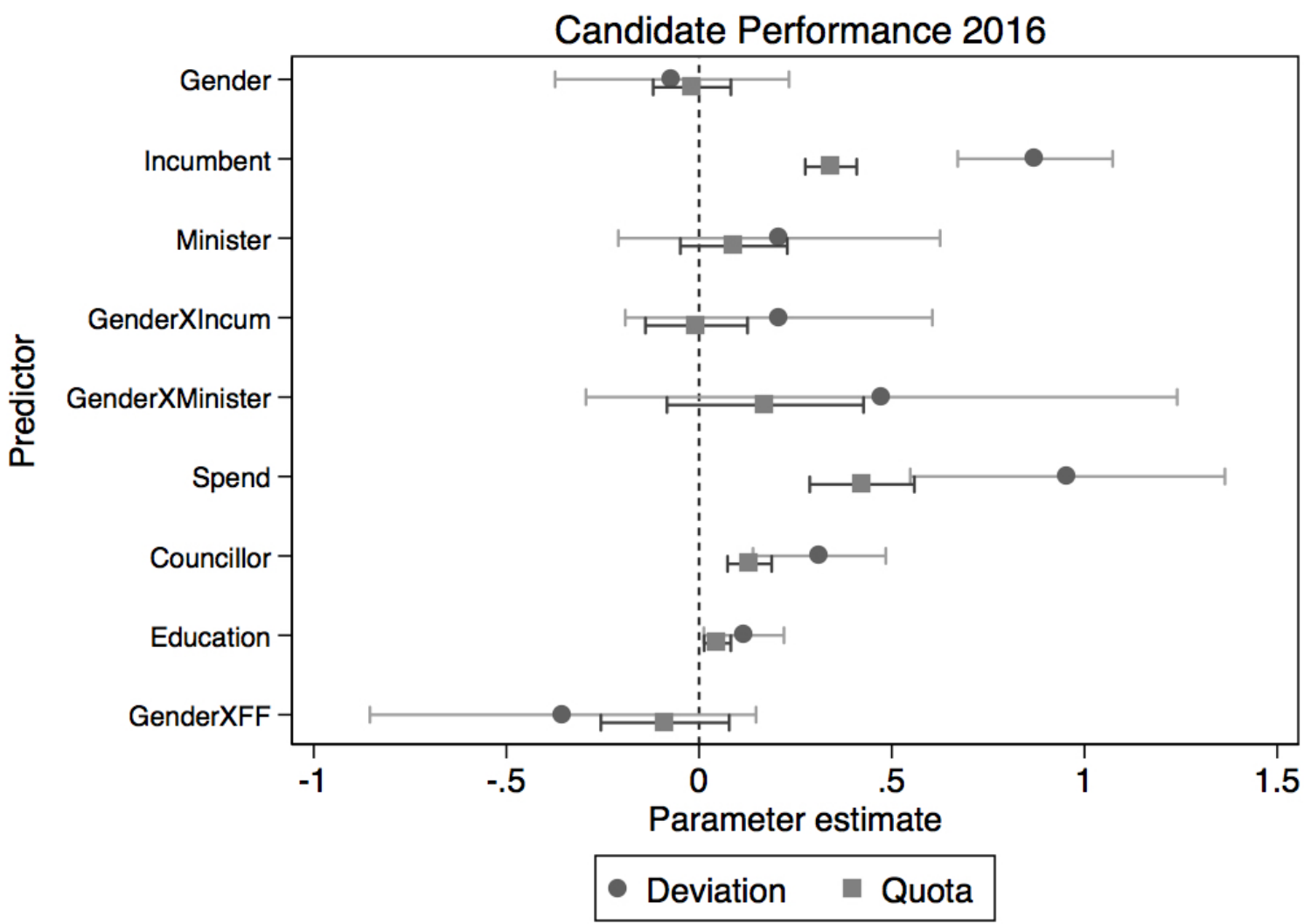


Figure 9.7A: Factors effecting voting for female candidates (any preference)

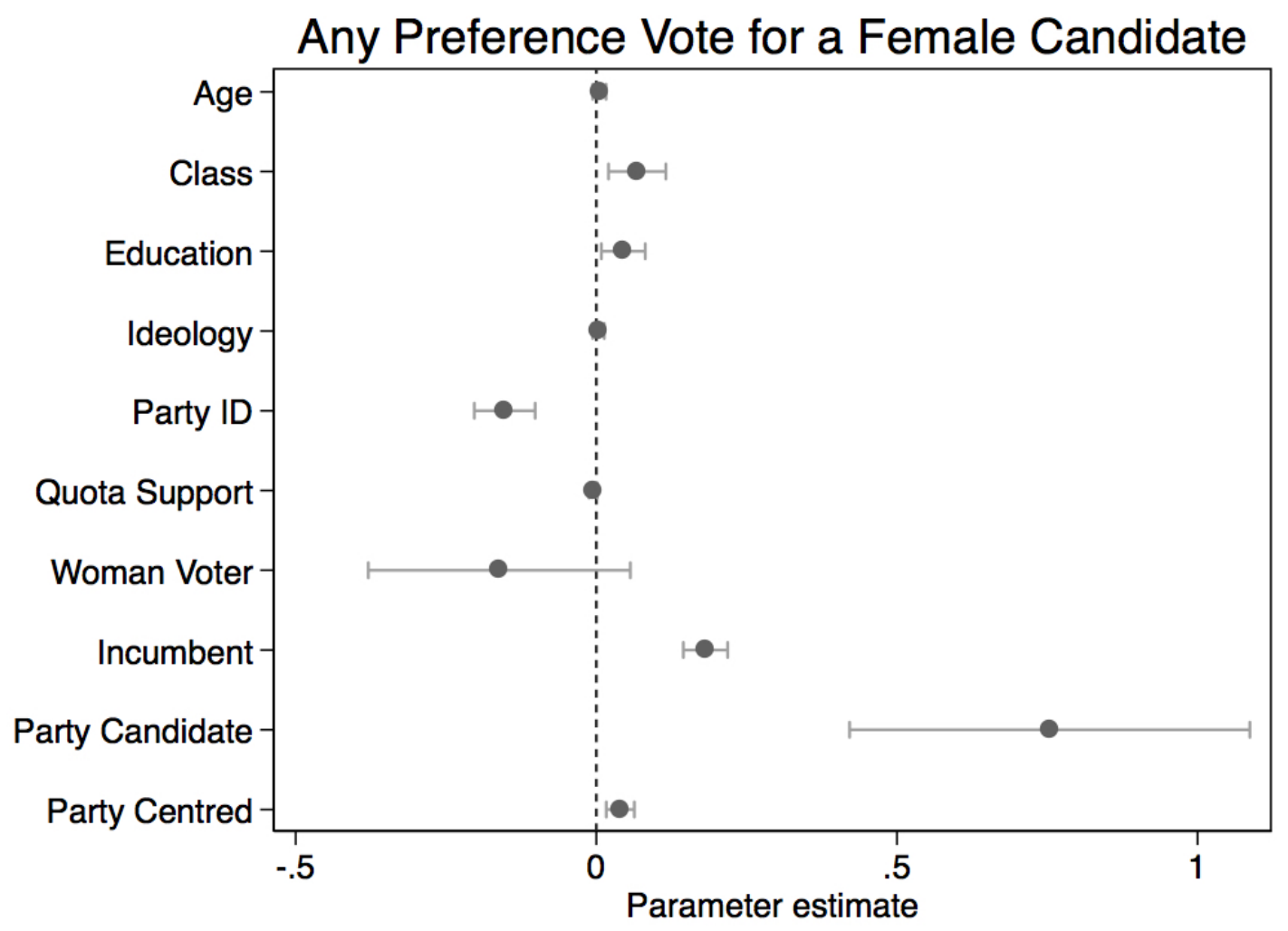

Figure 9.7a displays the results of a logit regression model that examines the relationship between individual voter characteristics and casting any preference for a female candidate. The dots represent the point estimates, while the horizontal lines depict $95 \%$ confidence intervals. The range of parameter estimates is displayed on the $x$-axis. Data Source: INES1. 
Figure 9.7B: Factors affecting voting for female candidates (high preference)

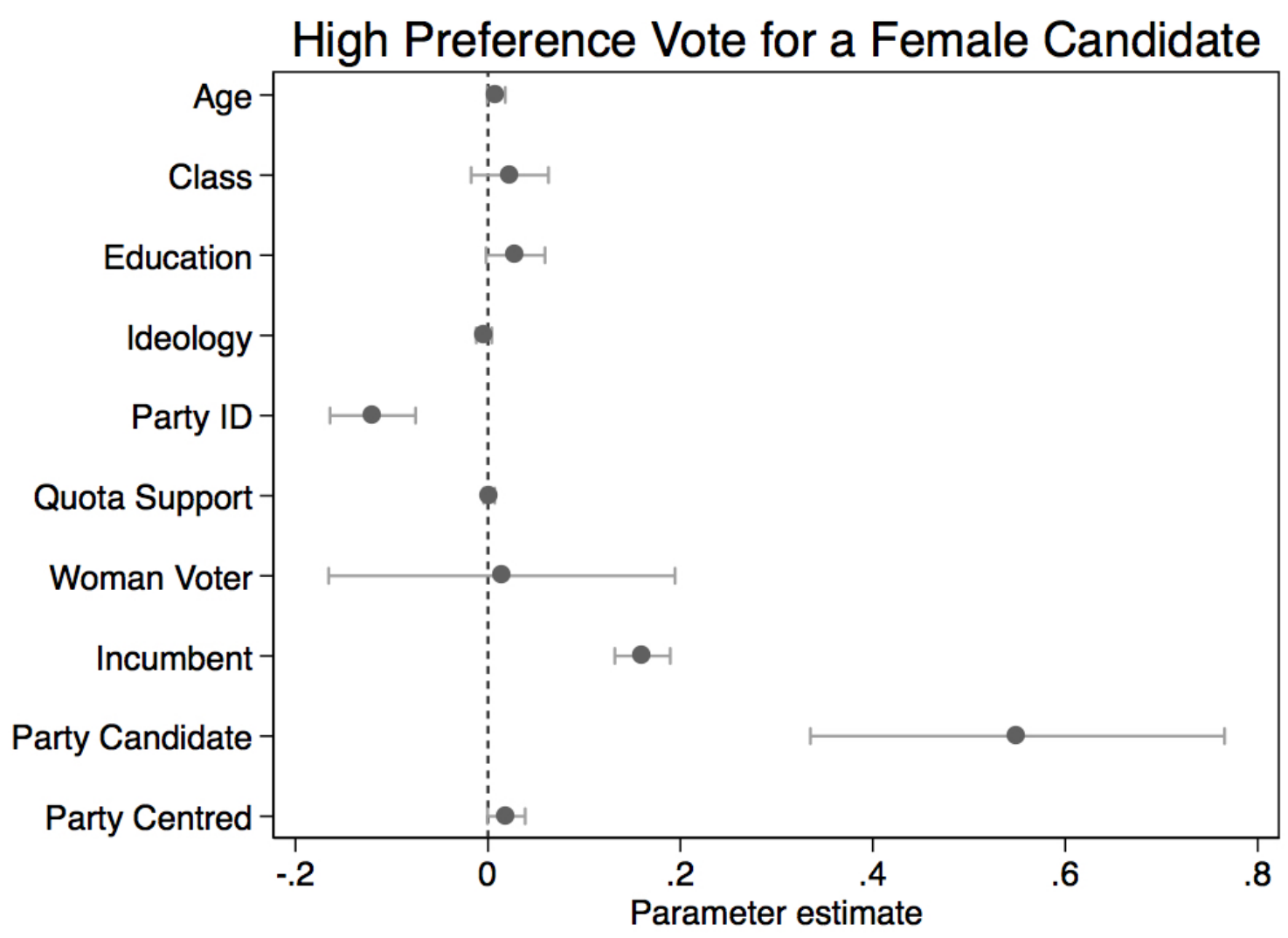

Figure $9.7 b$ displays the results of a logit regression model that examines the relationship between individual voter characteristics and casting a high preference vote (1-3) for a female candidate. The dots represent the point estimates, while the horizontal lines depict $95 \%$ confidence intervals. The range of parameter estimates is displayed on the x-axis. Data Source: INES1. 
Figure 9.8: Irish voter 'Big Five' trait distribution
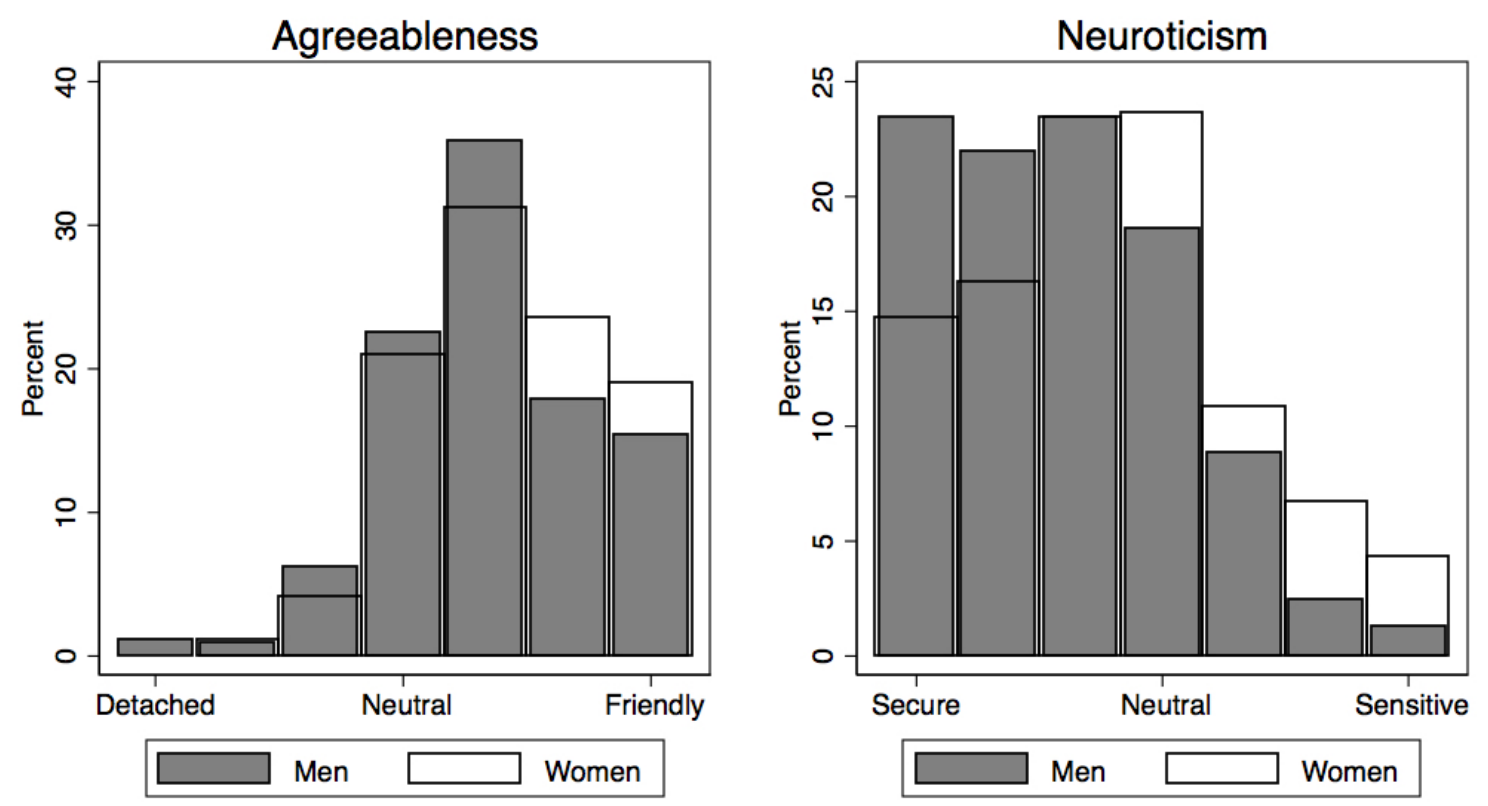

Data Source: INES3 
Figure 9.9: Impact of 'Big Five' traits on casting a first preference for a female candidate.

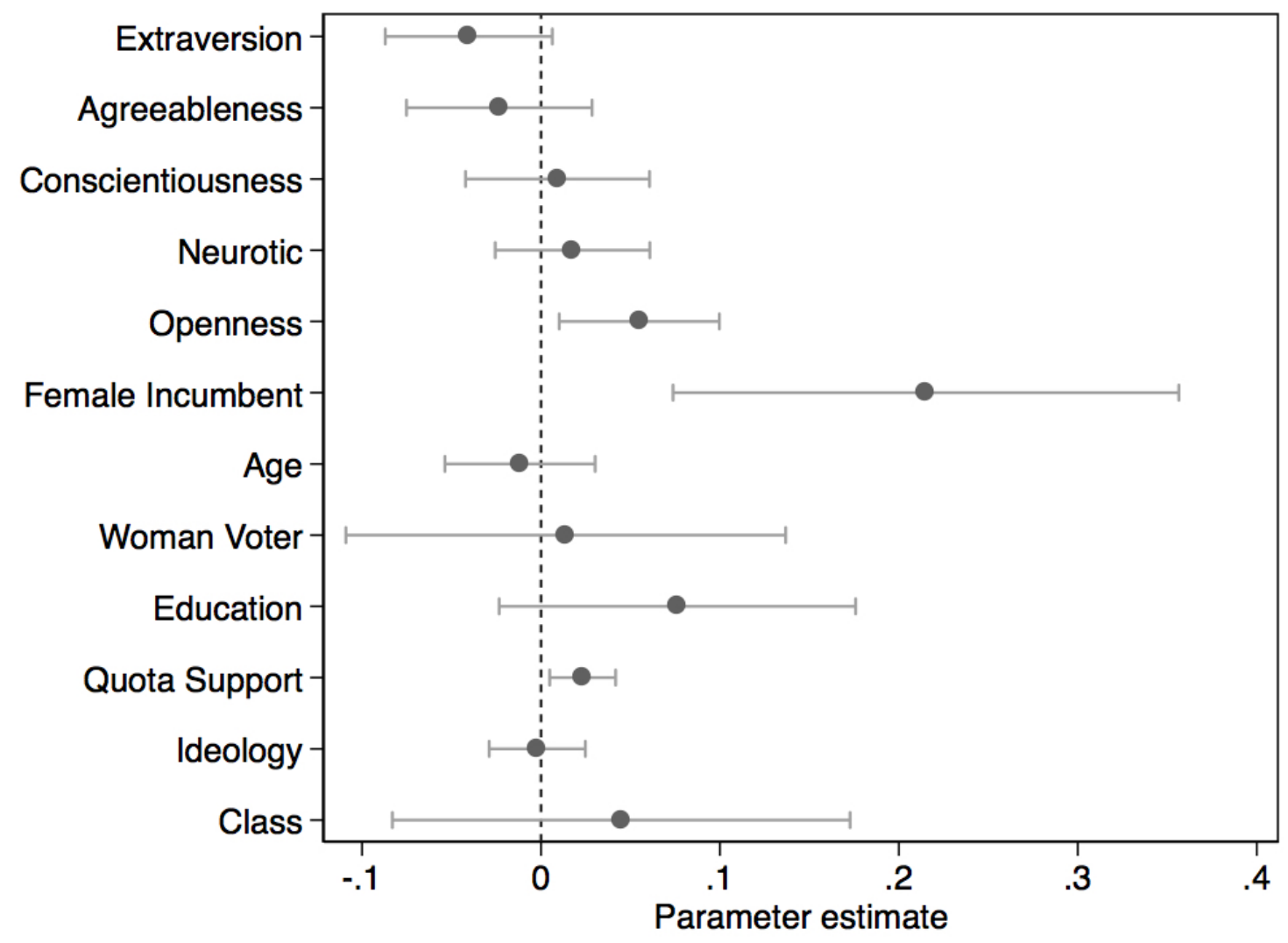

Data Source: INES3 
Appendix

Table A9.1: Aggregate analysis 2016

\begin{tabular}{|c|c|c|c|c|}
\hline & $\begin{array}{c}\text { Model } 1 \\
\text { Deviation }\end{array}$ & $\begin{array}{c}\text { Model } 2 \\
\text { Percent of Quota }\end{array}$ & $\begin{array}{c}\text { Model } 3 \\
\text { Deviation }\end{array}$ & $\begin{array}{c}\text { Model } 4 \\
\text { Percent of Quota }\end{array}$ \\
\hline \multirow[t]{2}{*}{ Gender } & 0.0771 & 0.0246 & -0.0245 & 0.0384 \\
\hline & $(0.91)$ & $(0.85)$ & $(-0.09)$ & $(0.42)$ \\
\hline \multirow[t]{2}{*}{ Incumbent } & $0.747^{* * *}$ & $0.289^{* * *}$ & $0.874^{* * *}$ & $0.344^{* * *}$ \\
\hline & $(10.16)$ & (11.52) & $(8.51)$ & (10.11) \\
\hline \multirow[t]{2}{*}{ Minister } & 0.133 & 0.0817 & 0.205 & 0.0865 \\
\hline & $(0.87)$ & $(1.57)$ & $(0.96)$ & $(1.22)$ \\
\hline \multirow[t]{2}{*}{ Gender X Incumbent } & 0.179 & 0.0105 & 0.201 & -0.0136 \\
\hline & $(1.22)$ & $(0.21)$ & $(0.98)$ & $(-0.20)$ \\
\hline \multirow[t]{2}{*}{ Gender X Minister } & 0.562 & 0.194 & 0.482 & 0.182 \\
\hline & $(1.77)$ & $(1.79)$ & $(1.23)$ & $(1.40)$ \\
\hline \multirow[t]{2}{*}{ Campaign Spend } & $1.086^{* * *}$ & $0.434^{* * *}$ & $0.957^{* * *}$ & $0.423^{* * *}$ \\
\hline & $(8.54)$ & (9.99) & $(4.60)$ & $(6.14)$ \\
\hline \multirow[t]{2}{*}{ Councillor } & $0.247^{* * *}$ & $0.0970^{* * *}$ & $0.313^{* * *}$ & $0.132^{* * *}$ \\
\hline & $(4.63)$ & $(5.33)$ & $(3.57)$ & $(4.52)$ \\
\hline \multirow[t]{2}{*}{ Fianna Fail } & $0.933^{* * *}$ & $0.307^{* * *}$ & $0.804^{* * *}$ & $0.241^{* * *}$ \\
\hline & $(10.22)$ & $(9.84)$ & $(6.21)$ & $(5.61)$ \\
\hline \multirow[t]{2}{*}{ Fine Gael } & 0.154 & 0.0241 & -0.0100 & -0.0563 \\
\hline & $(1.56)$ & $(0.72)$ & $(-0.07)$ & $(-1.17)$ \\
\hline \multirow[t]{2}{*}{ Labour } & $-0.368^{* *}$ & $-0.167^{* * *}$ & -0.363 & $-0.184^{*}$ \\
\hline & $(-2.92)$ & $(-3.87)$ & $(-1.57)$ & $(-2.41)$ \\
\hline \multirow[t]{2}{*}{ Sinn Fein } & $0.737^{* * *}$ & $0.259^{* * *}$ & $0.594^{* * *}$ & $0.201^{* * *}$ \\
\hline & $(7.31)$ & $(7.52)$ & $(3.80)$ & $(3.87)$ \\
\hline \multirow[t]{2}{*}{ Greens } & 0.0617 & 0.0298 & -0.0810 & -0.00941 \\
\hline & $(0.58)$ & $(0.82)$ & $(-0.44)$ & $(-0.15)$ \\
\hline \multirow[t]{2}{*}{ Renua } & -0.109 & -0.0482 & -0.279 & -0.119 \\
\hline & $(-0.88)$ & $(-1.13)$ & $(-1.36)$ & $(-1.74)$ \\
\hline \multirow[t]{2}{*}{ Anti Austerity Alliance } & 0.206 & 0.0522 & 0.00657 & -0.0523 \\
\hline & (1.66) & $(1.23)$ & $(0.02)$ & $(-0.59)$ \\
\hline \multirow[t]{2}{*}{ Gender X Fianna Fail } & $-0.589^{* * *}$ & $-0.185^{* * *}$ & -0.346 & -0.0798 \\
\hline & $(-3.81)$ & $(-3.50)$ & $(-1.35)$ & $(-0.93)$ \\
\hline \multirow[t]{2}{*}{ Gender X Fine Gael } & -0.125 & -0.0299 & 0.0611 & 0.0541 \\
\hline & $(-0.80)$ & $(-0.56)$ & $(0.25)$ & $(0.67)$ \\
\hline \multirow[t]{2}{*}{ Gender X Labour } & -0.244 & -0.0258 & $-0.718^{*}$ & -0.164 \\
\hline & $(-1.17)$ & $(-0.36)$ & $(-2.07)$ & $(-1.42)$ \\
\hline \multirow[t]{2}{*}{ Gender X Sinn Fein } & -0.208 & -0.0833 & -0.0490 & -0.0306 \\
\hline & $(-1.22)$ & $(-1.43)$ & $(-0.18)$ & $(-0.34)$ \\
\hline \multirow[t]{2}{*}{ Gender X Greens } & -0.0577 & -0.000157 & 0.00730 & 0.0137 \\
\hline & $(-0.30)$ & $(-0.00)$ & $(0.02)$ & $(0.13)$ \\
\hline \multirow[t]{2}{*}{ Gender X Renua } & -0.188 & -0.0479 & -0.0792 & -0.00942 \\
\hline & $(-0.83)$ & $(-0.61)$ & $(-0.13)$ & $(-0.05)$ \\
\hline \multirow[t]{2}{*}{ Gender X AAA } & -0.153 & -0.0127 & -0.0197 & 0.0870 \\
\hline & $(-0.77)$ & $(-0.19)$ & $(-0.05)$ & $(0.70)$ \\
\hline \multirow[t]{2}{*}{ Education } & & & 0.123 & $0.0562^{* *}$ \\
\hline & & & $(1.97)$ & $(2.70)$ \\
\hline Education X Gender & & & -0.0234 & -0.0290 \\
\hline & & & $(-0.20)$ & $(-0.76)$ \\
\hline Constant & $-0.829^{* * *}$ & $0.0457^{* *}$ & $-0.880^{* * *}$ & -0.00756 \\
\hline & $(-17.85)$ & $(2.88)$ & $(-6.24)$ & $(-0.16)$ \\
\hline$N$ & 551 & 551 & 272 & 272 \\
\hline
\end{tabular}

$t$ statistics in parentheses: ${ }^{*} p<0.05, \quad p<0.01,{ }^{* * *} p<0.001$
Note: OLS Regression with deviation from average number of $1^{\text {st }}$ preferences in constituency as dependent variable in Models 1 and 3. In models 2 and 4 the dependent variable is per cent of quota obtained by the candidate. 
Table A9.2: Casting a (high) preference for a female candidate, 2016.

\begin{tabular}{|c|c|c|}
\hline & $\begin{array}{c}\text { Model 1 } \\
\text { Any Preference }\end{array}$ & $\begin{array}{c}\text { Model 2 } \\
\text { High Preference } \\
\end{array}$ \\
\hline \multirow[t]{2}{*}{ Woman Respondent } & -0.837 & 0.102 \\
\hline & $(-1.45)$ & $(0.16)$ \\
\hline \multirow[t]{2}{*}{ Party Candidate } & $3.912^{* * *}$ & $3.892^{* * *}$ \\
\hline & $(4.47)$ & $(5.07)$ \\
\hline \multirow[t]{2}{*}{ Ideology } & 0.0181 & -0.0288 \\
\hline & $(0.71)$ & $(-0.99)$ \\
\hline \multirow[t]{2}{*}{ Party ID } & $-0.790^{* * *}$ & $-0.846^{* * *}$ \\
\hline & $(-5.85)$ & $(-5.19)$ \\
\hline \multirow[t]{2}{*}{ Class } & $0.353^{* *}$ & 0.161 \\
\hline & $(2.79)$ & $(1.11)$ \\
\hline \multirow[t]{2}{*}{ Age } & 0.0260 & 0.0606 \\
\hline & $(0.89)$ & $(1.78)$ \\
\hline \multirow[t]{2}{*}{ Education } & $0.233^{*}$ & 0.203 \\
\hline & $(2.41)$ & $(1.83)$ \\
\hline \multirow[t]{2}{*}{ Quota Support } & -0.0286 & 0.00972 \\
\hline & $(-1.58)$ & $(0.47)$ \\
\hline \multirow[t]{2}{*}{ Party Centred } & $0.207^{* * *}$ & 0.135 \\
\hline & (3.34) & $(1.92)$ \\
\hline \multirow[t]{2}{*}{ Incumbent } & $0.942^{* * *}$ & $1.136^{* * *}$ \\
\hline & $(9.61)$ & $(10.83)$ \\
\hline \multirow[t]{2}{*}{ Woman X Party Candidate } & 0.0243 & 0.154 \\
\hline & $(0.04)$ & $(0.30)$ \\
\hline \multirow[t]{2}{*}{ Woman X Ideology } & -0.0450 & 0.0611 \\
\hline & $(-1.08)$ & $(1.29)$ \\
\hline \multirow[t]{2}{*}{ Woman X Party ID } & 0.155 & -0.312 \\
\hline & $(0.72)$ & $(-1.13)$ \\
\hline \multirow[t]{2}{*}{ Woman x Class } & -0.231 & 0.0322 \\
\hline & $(-1.23)$ & $(0.15)$ \\
\hline \multirow[t]{2}{*}{ Woman X Age } & 0.0521 & -0.0270 \\
\hline & $(1.13)$ & $(-0.52)$ \\
\hline \multirow[t]{2}{*}{ Woman X Education } & 0.211 & -0.0912 \\
\hline & $(1.34)$ & $(-0.52)$ \\
\hline \multirow[t]{2}{*}{ Woman X Quota Support } & 0.0361 & -0.00728 \\
\hline & $(1.21)$ & $(-0.21)$ \\
\hline \multirow[t]{2}{*}{ Woman X Party Centred } & -0.157 & -0.0376 \\
\hline & $(-1.62)$ & $(-0.34)$ \\
\hline \multirow{2}{*}{ Constant } & $-1.917^{* * *}$ & $-2.499^{* * *}$ \\
\hline & $(-5.98)$ & $(-6.71)$ \\
\hline$N$ & 3658 & 3658 \\
\hline
\end{tabular}


Table A9.3: Big Five Questions

I am going to read some statements that describe people Please indicate whether you completely agree, somewhat agree, partly agree, partly disagree, somewhat disagree, or completely disagree with each of the statements I...

\begin{tabular}{|l|l|}
\hline & Trait Measured \\
\hline am reserved & Extraversion (reversed) \\
\hline am generally trusting, believe in the good in people & Agreeableness \\
\hline tend to be lazy & Conscientiousness (reversed) \\
\hline am relaxed, handle stress well & Neuroticism (reversed) \\
\hline have few artistic interests & Openness (reversed) \\
\hline am outgoing, sociable & Extraversion \\
\hline tend to find fault with others & Agreeableness (reversed) \\
\hline do a thorough job & Conscientiousness \\
\hline get nervous easily & Neuroticism \\
\hline have an active imagination & Openness \\
\hline
\end{tabular}

